\title{
Imperfection of the World Trade Organization as a Hazard for International Business
}

\author{
Krystyna Zoladkiewicz, Renata Orlowska
}

\author{
University of Gdansk \\ Bazynskiego 8, 80-309 Gdansk, Poland \\ E-mail.krystyna.zoladkiewicz@ug.edu.pl; renata.orlowska@ug.edu.pl
}

cross $^{\text {ref }}$ http://dx.doi.org/10.5755/j01.ee.31.3.24346

\begin{abstract}
This paper examines the negative impact of the paralysis observed in the World Trade Organization (WTO) functioning on international business. We provide an overview of the loopholes in the WTO rules and principles which became serious threats for the multilateral trading system. Our research identifies important loopholes in the MFN clause, DSB and Appellate Body. We bring clarity that the paralysis observed in the WTO functioning is a consequence of these factors. The deviations and exceptions of the WTO rules permit the WTO members to compete "unfairly". China is among the economies which are the most efficient in this respect. We term China's behaviour on the global market as "economic factitious disorder". It can be explained as permanently maintaining the status of a developing country by China and using preferences for LDCs despite a really high level of economic development. These findings indicate that the WTO lacks the mechanism to react and to prevent such abuses. They were not envisaged by the WTO creators, which suggests the need of the WTO reform. We contribute to international business research and the international organizations literature by identifying the causes of the paralysis of the WTO functioning.
\end{abstract}

Keywords: Multilateral Trading System; International Business; WTO; MFN; DSB; Appellate Body.

\section{Introduction}

Over the years, international business research has shown that the multilateral trading system can benefit the global economy (Appleyard \& Field Jr., 2014; Bagwell, Bown \& Staiger, 2016; Baier \& Bergstrand, 2007; Chang, 2011; Das, 2007; Gonzalez \& Veron, 2019; Sun, Heshmati 2010; vanGrasstek, 2013; Reinert, 2012; Wagner, 2011; Wolf, 2001). The multilateral trading system rests on the idea that non-discrimination based on the most-favoured nation (MFN) and national treatment (NT), as well as transparent trade policies, fair competition, and open markets are beneficial to all countries. This concept first led to the creation of the General Agreement on Tariffs and Trade (GATT) in 1947 and then has been embodied in the World Trade Organization (WTO) since 1995. The multilateral trading system is a rules-based regime where members together liberalise world trade. It is to include the world as a whole - developed, developing, and the least developed economies. Negotiation rounds are the driving force of the system. Therefore the WTO was perceived as one of the most important achievements of the international economics in the modern world economy. It was sometimes commonly termed 'global integration'.

The WTO currently has 164 members and accounts for 98 per cent of global trade (WTO, 2019a). It is a forum for multilateral trade negotiations (MTNs). To date, eight rounds of MTNs were held under GATT auspices. The first WTO round, called Doha Development Agenda (DDA) or Doha Round was launched in 2001, and was supposed to be concluded by 2005 (WTO 2009; Zedillo, 2007). In 2006, the first signal of Doha Round fiasco and the possible breakdown of the multilateral trading system were announced by some researchers and politicians (Akyuz, Milberg \& Wade, 2006; Wilkinson, 2007). The following years have not changed much, which decreased the enthusiasm for multilateralism, and the WTO (Bagwell, Staiger, 2014; Bhagwati \& Sutherland, 2011; Jones, 2015; Lester, 2016). In 2008, Zoellick, the President of the World Bank Group during 2007-2012, advised to start with new multilateralism: "Even as the United States and the world dig out of the present hole, we need to look further ahead: We must modernize multilateralism and markets for a New Global Economy. (...) The New Multilateralism, suiting our times, is likely to be a flexible network, not a fixed system. It needs to maximize the strengths of interconnecting actors, public and private, profit-making and civil society NGOs." (Zoellick, 2008: 2). Eight years later, Lester (2016:2) asked the question: "Should the WTO continue working on the Doha agenda, trying to complete the outstanding items? Or should it move on to other issues, and, if so, which ones?"

There is substantial evidence pointing to the causes of the Doha Round negotiation's failure. It would seem that everyone agrees with the need for change. Having said that, we ask a simple question: To what extent this impasse affects international business to make this change a real need?

The legitimacy and effective functioning of the WTO are currently under serious threat for the multilateral trading system (Brown, 2012; Howse, Nocolaidis, 2003). The breakdown of the multilateral trading system is becoming more and more real. The paralysis observed in the WTO negatively affects international business (Pauwelyn, 2005). Azevedo (the WTO current Director-General) said: "I would say this is the worst crisis not for the WTO but for the whole multilateral trading system since the GATT in 1947" (Gallas, 2018). We identify with Deblock's opinion (2017:2), who states: "That is the point: the world has changed, regionalism has changed, but what about the WTO?" Nevertheless, at this point we draw attention to a 
very important issue: the WTO means Member States, not an organization as an institution. Analysing the WTO imperfections, with full responsibility, we want to point out that the criticism is not addressed to the WTO Secretariat, or any other WTO's body, it is directed to all Member States. In the case of the WTO, differently from other international organizations, each Member State has the same weight of its vote (WTO, 2019).

A key challenge for understanding more about the paralysis in the WTO functioning has to do with the loopholes in the organization's rules and principles. The deviations and exceptions of the WTO rules permit its members to compete "unfairly" (Hoekman \& Kostecki, 2009; Ismail, 2005).

Our paper identifies important loopholes in the WTO rules. Although there are numerous studies of multilateral trade system (Feng, Li \& Swenson, 2017; Larch et al., 2019), there is little systematic evidence specifically on the WTO loopholes. Moreover, the previous studies analysed separately each of the loopholes without emphasizing their interrelations (Davey, 2005; Henderson, 2003; Wroblewski, Stecz, 2019).

We investigate that the current WTO paralysis is more complex, involving a whole range of inter-related causes. To fill the gap in the literature, we aim to analyse interrelations of the loopholes in the WTO rules which we consider the most important determinants reducing the WTO's efficiency.

The major contribution of our research is threefold. First, we add to the literature on the WTO non-discrimination and reciprocity principles. The most-favoured-nation principle (MFN) is one of the pillars of non-discrimination. Article XXIV ("provides for the formation and operation of customs unions and free trade areas covering trade in goods"), enabling clause ("allows developing country members when entering regional or global arrangements to reduce or eliminate tariffs in trade in goods among themselves") and Article V ("governs economic integration agreements in the area of trade in services, for both developed and developing countries") (WTO, 2019a) are the exceptions and already in their essence diminish MFN principle being contradictory to its idea. Article XXIV causes various different observations among researchers. For some of them it provides the elasticity in a rigid principles (Curzon, 1965), but for others it allows for omitting multilateralism (Bhagwati, 1993; Haight, 1972). Drawing on these different opinions, we observed that after 25 years of WTO's functioning these exemptions became a rule. Thus, it leads us to the conclusion that WTO should concentrate more on legislative changes to adjust to new face of global economy.

Second, we contribute to the literature on fair competition in international business and methodology concerning the WTO members' classification due to economic development. Today, the economic power is shifting toward developing countries, so the WTO must reflect on this change. The problematic issue in this respect may seem that the WTO allowed its member states to selfdeclare a level of their development and announce a formal categorization whether they are developed or developing countries. There is no WTO definition and criteria of level of development. Such a situation may cause dissatisfaction of all these member states with slower economic growth in the last years compared to some developing countries, and those countries which were earlier defined as developed. On the one hand, they do not benefit from the privileges and exceptions offered for the developing countries. On the other hand, they may have the impression that some of the developing countries have long become developed economies and impair the WTO rules. The lack of proper classification leads to numerous business disputes (Wroblewski \& Stecz, 2019). At the same time dispute settlement mechanism considered to be a spectacular achievement of the WTO appeared to be one of the loopholes (Caporal et al., 2019; Davey, 2005, 2009; Matsushita, 2012). The novelty in the system, the Appellate Body (AB) happens to be the weakest point (Chidede, 2018; Ehlermann, 2017). Our results suggest the need of introducing the adequate typology of WTO members' level of economic development. It aims to eliminate the situation we term as an economic factitious disorder.

In our research we do not focus very much on micro-, and macroeconomic evidence of the increasing protectionism on international business. Such evidence is well known (Guarino, 2018; Hilton, 2017; Wolf, 2005).

This paper is organized as follows. First, theoretical background is provided on the role of the WTO in international business. Second, research methodology and underlying data are described. The third section provides the results of exemptions from the WTO principles and rules. The last section concludes this research and discusses the results and implications.

Our study is based on the observation, our business and diplomatic experience, scientific on the one hand and business oriented literature review on the other. Scientific and political debate on the WTO imperfections has been going on for nearly two decades.

\section{Theoretical Background}

From the time of Adam Smith in 1776 to the launch of GATT in 1947, international trade theories have evolved quite slowly. However, since the introduction of GATT in 1947, there have been many significant modifications and new approaches (Krugman, Obstfeld \& Melitz, 2012; Vernon, 1979; Trebilcock \& Howse, 1999).

It is mostly accepted that international trade of goods and services drives benefits for both economy and business. A link between openness, trade and growth has been discussed among economists. On the one hand Greenaway, Morgan and Wright (2002) argued that there is a positive relationship between openness, trade and growth confirmed by results of their empirical research. Salvatore (2012) indicates positive impact of trade (with a sufficient increase in the volume) on nation's better off. Ben-David and Loewey in 1997 (Hoekman \& Kostecki, 2009: 16) indicated the importance of trade openness for sustained increase of economic growth as essential factor in lowering poverty rate. Studies by Sachs and Warner (1995) and Pilinkiene (2016) found that open economies grew faster than closed ones. Contrary to the above, sceptics demonstrate that there is a positive relation but it is the growth that contributes to openness rather than vice versa. However, Wachiarg and Welch (2008) argued and showed the evidence for years 1950-1998 that countries with more opened economies were growing faster (at rate of 1.5 per cent higher) than closed economies. 
Ethier (1995) noted that due to openness of markets countries will experience economic growth. He indicated that liberalism through minimal restrictions on international trade should be accompanied by a symmetry, meaning that all nations should be treated the same. However, the evolution of trade policy can be viewed as the result of two forces, often acting in conflict. In the literature on international business there is a theoretical rationale for both liberalism and protectionism. Study in this area usually focuses on the causes and benefits of international trade, taking into account these two aspects, whether economic policy should be more liberal or protective (Mlinaric, Oplotnik \& Brezovnik, 2018; Lawrence, 2018; Wu, 2007).

Fears of increased protectionist moods led to the creation first, in 1947 of the GATT and then in 1995 of the World Trade Organization (WTO). Their aim was to establish and maintain a rules-based regime where members will together reduce trade barriers. The system was to include the world as a whole - developed and developing countries, and least developed economies. The WTO is perceived as one of the most important achievements of the international economics in the modern world economy (Pomfret, 2008; Drabek, 2010; Gallagher, 2005). It is sometimes commonly termed 'global integration'.

The WTO emerging at the end of the 20th century, when the world had a completely different architecture, was based on the foundations of the past, post-war rules. Among its pillars (among others) were the most-favoured-nation (MFN) clause and Article XXIV and Article V as exceptions in the context of the principle of the reciprocity. The WTO was created on assumption of universal organization and introduced the Appellate Body (AB), so called "international tribunal" which was to supplement the Dispute Settlement Body (DSB).

The WTO system is built on the pillar of the reciprocity connected with the idea of symmetry. This guiding principle should be understood that all nations are treated in the same manner (Ethier, 1995). So, the first problem arises when we talk about asymmetry. Another problem was related to asymmetry in the context of the WTO economic rules versus power addressed by Bagwell and Staiger (2002). They referred to the specificity of the principle of reciprocity addressing "asymmetries" of rules versus power. On the one hand they presumed that reciprocity may help smaller economies to fight with their anxiety due to power "asymmetries" vis-à-vis more powerful negotiating trading partners. Bagwell and Staiger (2002:68) argued that “governments are 'penalized' under GATT's reciprocity rule if they seek to negotiate an outcome on the efficiency frontier other than the political optimum".

There should be no doubt that the establishment of the WTO was one of the most important steps in the development of the global economy. However, increasing criticism about the results of the WTO triggers a discussion on the part of both scientists and politicians. "The WTO is not what it used to be a decade or so ago" (Carbonnier 2012: 137).

An exacerbated conviction started in 2006 of the failure of the Doha Development Agenda (DDA) of the WTO. It has been strengthen by warnings about an increase in protectionist, a possible collapse of the multilateral trading system and, in the most exorbitant scenarios, fragmentation of the global economy (Akyuz, Milberg, Wade, 2006; Bellmann,
Hepburn, Wilke, 2012; Briscoe, Guha, 2006; Kernohan, Edwards, 2006; Wilkinson, 2007).

Due to Leidy and Hoekman any trade negotiations can be analyzed in four subsequent stages: catalyst, pre-negotiation, negotiation, and post-negotiation (Hoekman, Kostecki, 2009). Decomposition of Doha Round according to this structure will show that from the very beginning this round of negotiations was doomed to failure (Gantz, 2013). There were many different factors that have had an impact on it. Among them: "single undertaking" principle, groups of interests (lobbying) influencing governments, emancipation of developing countries, new superpowers and change in the world architecture, to mention a few. It can be argued that fiasco of the Doha Round may be recapitulated in Bergsten's "bicycle theory of trade liberalization: if the system is not moving forward with the new market opening initiatives, it may fall over into protectionism" (VanGrasstek, 2013: 280). The evidence from this is confirmed by recent global trade events and the growing protectionist steps of the biggest players. And this is currently what the most developed economies (vide: US) and developing countries (vide: China) are doing (Fetzer, Schwarz, 2019; .Noland, 2017)

The current impasse in the WTO means that there is a vigorous debate about the lack of a transparent road to the liberal world (Baldwin, Evenett, 2009). There are three avenues to liberalization: unilateral, bilateral, regional and multilateral (Panagariya, 2007). Unilateral means: Go on your own-lower your barriers to all without others necessarily doing the same; Regional: Go with another country-lower your barriers to the partner only in return for similar action by the partner; Multilateral: Go with the WTO-lower your barriers to all in return for others lowering their barriers to you (in some cases, others lower their barriers even when you do not do the same).

\section{Methodology}

The research methods used in this paper include the analysis of scientific literature, policy and legal documents, analysis of the findings from secondary sources of empirical research as well as synthesis, summary, and interpretation of data. Some empirical findings from interviews with the WTO executives are also integrated into the analysis.

To achieve our aim we use the cause-and-effect analysis (Ishikawa diagram) to identify the loopholes in the WTO rules and their interrelations (Figure 1).

First, we discuss the concept of the Most Favoured Nation (MFN) principle and the key idea behind its importance. We highlight the main exceptions to the application of the MFN, namely Article XXIV, enabling clause and Article V. Their negative effects are regional trade agreements (RTAs) leading to fragmentation at the organization.

Second, we present the Dispute Settlement Body (DSB) and the WTO Appellate Body (AB). We analyse the dispute settlement (DS) cases involving developing countries and recent DS cases involving US and China. We point out that the lack of any classification or any benchmarks at the WTO to determine and proper recognition as a "developed" or "developing" country leads to abuse the privileges due to "special and differential treatment" (S\&DT). We discuss the causes of the $\mathrm{AB}$ crisis. 


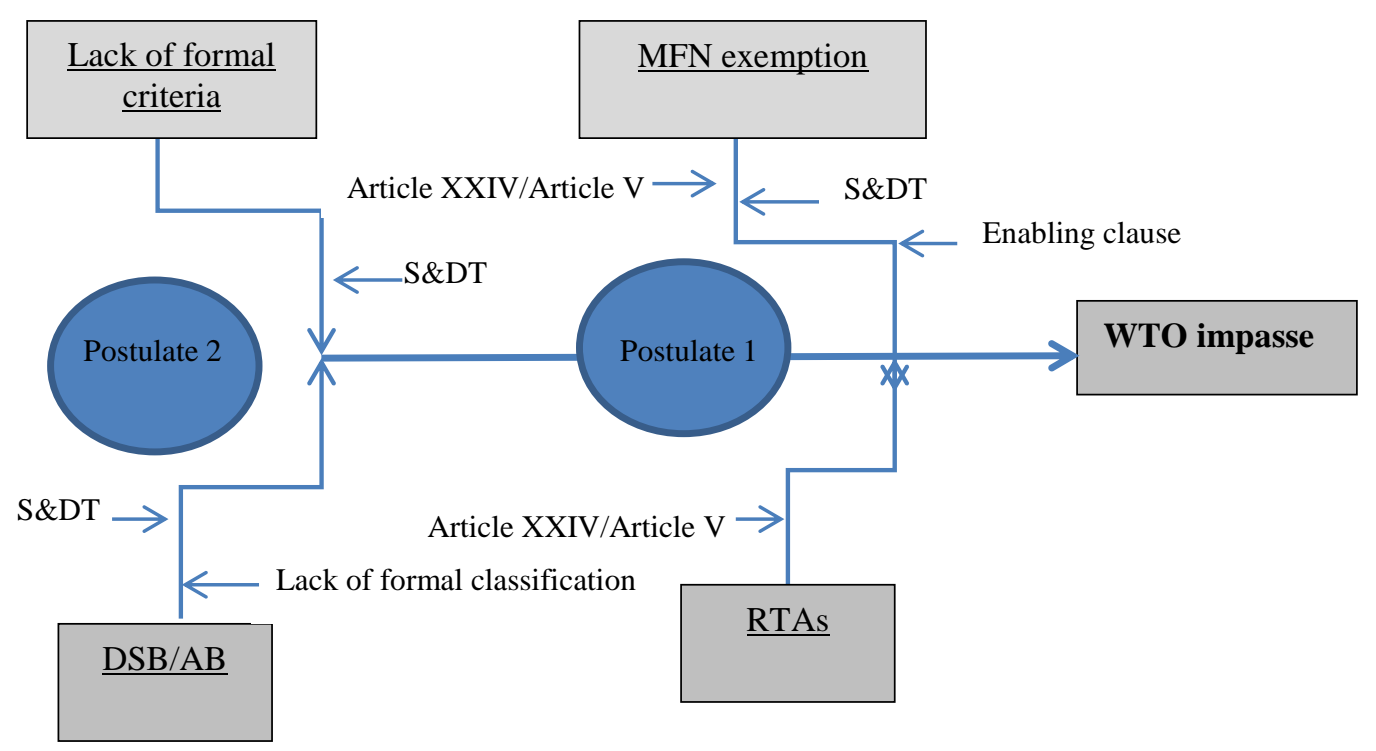

Figure 1. Cause-and-Effect Analysis Model (CEA) Source: own collaboration.

The data about RTAs was obtained from the WTO Regional Trade Agreements database of all RTAs notified to the GATT/WTO, which includes data from the year 1948 (WTO, 2019b). The information on the WTO dispute settlements was obtained from the disputes database of the WTO (WTO, 2019c).

\section{The WTO principles, rules and their exemptions}

\section{Most favoured nation (MFN)}

The MFN rule defines that countries cannot normally discriminate between their trading partners (giving them equally MFN status). "Any advantage, favour, privilege or immunity granted" to the product made by one country are to be "accorded to the like product" of other nations under the WTO agreements. In other words, if a country grants the other nation a special favour, for example a lower customs duty rate for one of their products it should do the same for all other WTO members (like product). So it means "favour one, favour all" principle. MFN clause applies immediately and unconditionally. The reciprocity is unconditional. An advantage of using the MFN rule is that it reduces costs of negotiations as their results are extended to other members. This principle is important for smaller economies due to certainty that they will not be exploited by larger countries. It also applies to trade measures towards services and service suppliers ("like service and service suppliers"). With regard to the protection of intellectual property it states that "any advantage, favour, privilege or immunity granted by a Member to the nationals of any other country shall be accorded immediately and unconditionally to the nationals of all other Members". So, MFN principle refers to trade in goods (Article 1 of GATT), services (Article 2 of GATS) and issues connected with Trade-Related Aspects of Intellectual Property Rights (Article 4 of the Agreement on TRIPS). Together, those three agreements cover important areas of the WTO activities.
Nevertheless, there are also exceptions to the application of the MFN. Among them regional trade agreements (RTAs) are exempt from applying MFN towards their non-members due to Article XXIV, enabling clause and Article V. It can mean then that RTAs diminish the role of MFN. It does not require reciprocity. Our first postulate $(\mathrm{P} 1)$, based on the preceding discussion, is as follows:

P1: MFN's exemptions encourage regional avenues of liberalization instead of multilateral avenue. These exemptions become rules.

Regional trade agreements (RTAs) are not a new phenomenon, but in the last 25 years we observe the threatening increase of number, the diversity of members and the scope of them (Table 1). When Bhagwati (2002) called the increase in RTAs as a "bowl of spaghetti", there were 36 of them in force, today (04.10.2019) we have 302 RTAs in force (WTO, $2019 \mathrm{~b}$ ), and we should rather talk about the "big pot of spaghetti". This dynamic proliferation of RTAs, forces the question whether RTAs facilitate economic liberalization or rather promote economic protectionism. Liberal economists consider RTAs as an obstacle to liberalization. They state that the best solution to achieve multilateral trading system is to speed up MFN liberalization (Panagariya, 2000). Other researchers claimed, that despite some potential dangers, RTAs are in fact accelerating the multilateral trading system (Baldwin, Evenett, Low, 2009). However, most of active RTAs include goods, not services and capital flows, moreover, many of them have limited membership, what severely limits the liberalization (Lynch, 2010). Today, the memorable phrase of Bhagwati (1991), whether trade blocks serve as "bricks" or "obstacles" for world liberalism, seems to be even more valid.

Extant research is focused to a large extent on the latest mega-regional initiatives with a completely new scale. The new avenue to liberalization, as combination of bilateralism and regionalism has been created. It is termed as megaregionalism or cross-regionalism. 
On the one hand, economists analyse how much RTAs are accelerating or not a multilateral trading system, on the other hand, lawyers are discussing the legality of RTAs. We agree with that an unclear WTO rules on regional trade agreements require a deep analysis of the WTO's legitimacy (Devuyst, Serdarevic, 2007; Acharya et al., 2016).

The rapid increase of RTAs in the last years could be an evidence of the WTO imperfection. RTAs, liberalizing trade between members, tighten protectionism with third countries what is in contradiction with the idea of the WTO's multilateral trading system.

As long as exceptions from the MFN will be easy to use, multilateral trading system will be a dream. After 25 years of WTO activity, the exception in the form of Article XXIV, enabling clause and Article V became the rule. We can therefore see a divergence between the number of RTAs established by countries and the ability, willingness and effectiveness of countries to enforce multilateral trading system. Most of RTAs are limited to trade of goods only (Table 1), what cannot be an evidence that regionalism is an efficient avenue to trade liberalization.

RTAs should be a temporary way for multilateral trading system only. In this point of view the WTO members should reconstruct both articles. From the very beginning, Article XXIV was a serious violation of the basic principle of GATT regarding the most-favoured treatment. We agree with Baldwin's argument that regionalism was a positive phenomenon, but the goal is multilateralism (2006). Therefore, regionalism should be more multilateral. Baldwin's (2006) concept of multilateralization of regionalism which was developed later in Baldwin and Low (2009) tackles the problem. A key component of the analysis of multilateralization is a process that would rationalize trade relations on more global basis of untamed tangle' of crisscrossing preferential trade agreements.

It would results in an significant increase in tariffs in the world as countries would no longer obliged to follow the MFN principle. It is time for the WTO to think about establishing a timetable for moving from regionalism to multilateralism. Otherwise, the dynamics of growth of RTAs will not be reduced, and will lead to increased fragmentation being an important obstacle for international business. For example, Caporal et al. (2019) estimate that proliferation of RTAs would result in a significant increase in U.S. tariffs across the board. They underline that the U.S. trading partners would no longer be obliged to apply MFN rule.

The OECD (2019) estimation suggests that RTAs are signed between countries that already have significant trade between them. This interesting finding suggests that RTAs do not accelerate the multilateral trading system.

Building on previous work (Pal, 2008; Sorgho, 2016; Ullah \& Inaba, 2011) we argue that gains from RTAs are doubtful while the proliferation of RTAs has globally negative effect on trade.

Table 1

RTAs in the GATT/ WTO 1948-2019 by Type of Agreement

\begin{tabular}{|c|c|c|c|c|}
\hline & Enabling clause & GATS Art. V & GATT Art. XXIV & Grand total \\
\hline Customs Union & 7 & & 11 & 18 \\
\hline Customs Union - Accession & 2 & & 10 & 12 \\
\hline Economic Integration Agreement & & 153 & & 153 \\
\hline Economic Integration Agreement - Accession & & 7 & & 7 \\
\hline Free Trade Agreement & 17 & & 240 & 257 \\
\hline Free Trade Agreement - Accession & 1 & & 3 & 4 \\
\hline Partial Scope Agreement & 28 & & & 28 \\
\hline Partial Scope Agreement - Accession & 2 & & & 2 \\
\hline Grand total & 57 & 160 & 264 & 481 \\
\hline
\end{tabular}

Source: Data from WTO, $2019 b$.

The simple existence of RTAs does not necessarily guarantee that multilateral trading system will be the next step. The huge number of RTAs created after the WTO establishment in 1995 (435 notifications of RTAs, WTO, 2019b) confirms that the Article XXIV, enabling clause and Article $\mathrm{V}$ aren't longer an exemption of MFN clause (WTO, 2019b) and they have become a solution for deepening liberalization without WTO participation. Haddoud, Jones and Newbery (2015) explored that Algeria and the European Union Regional Trade Agreement (Algeria-EU RTA) has positively influenced Algerian trade and led to an increase in economic welfare omitting the difficulties with the WTO accession process (which has lasted for 32 years).

Our findings confirm that increased number of RTAs and MFN exemptions are the causes of the current WTO paralysis and there is an interrelation between them. On the one hand, exemptions of MFN principle encourage countries to create new RTAs. On the other hand proliferation of RTAs diminish the MFN rule.

\section{Dispute Settlement Body (DSB) and Appellate Body (AB)}

Dispute settlement (DS) is the central pillar of the multilateral trading system. It belongs to the core activities of the WTO. The WTO dispute settlement procedures are a unified set of rules which provide access to resolving trade disputes of members. DS is elaborate and legally binding. The main responsibility for administering these rules and procedures lies with the Dispute Settlement Body (DSB). Disputes are brought to DSB by the government of the member states. It can be done under a judgment of violating an agreement or a commitment made in the WTO by a member government to another member government. It should be preceded by consultations on a bilateral level. The procedure further allows governments to apply for next steps (panels, rulings, recommendations). This is all part of DSB's competence and the WTO's unique contribution to the stability of global economy.

The DSB also establishes a standing Appellate Body (AB), being a kind of international court of appeal (tribunal). However, it is important to know that the term 
,tribunal' is not an official name in the WTO Agreement. It is also not an official definition of the $A B$. The $A B$ complements the dispute settlement system. The AB consists of seven lawyers, experts, with high reputation in law and international trade. The appointed persons serve for a four-year term (with a possibility to be reappointed once), and may not be affiliated with any government. They serve in rotation determined by the working procedures of the $\mathrm{AB}$. They cannot participate in any disputes that would create conflict of interest. The Appellate Body reports are adopted by the DSB.
The dispute resolution procedure in WTO is based on „Understanding on Rules and Procedures Governing the Settlement of Dispute“ (Annex 2, WTO Agreement, 2017). This Understanding applied only to requests for consultations made after the entry into force of the WTO from 1 January 1995, as stated (art. 3.2) "it serves to preserve the rights and obligations of Members". It is "a central element in providing security and predictability to the multilateral trading system". The Understanding is based on modified version of Article XXIII of the GATT 1947 (WTO Agreement, 2017).

Table 2

Summary of Dispute Settlements: the United States as Complainant and Selected Developing Countries as Respondents, since their WTO Membership

\begin{tabular}{|c|c|c|}
\hline Country & Total & In 2015-2018 \\
\hline China* & 23 & \\
\hline Hong Kong, China & 0 & \\
\hline Macao, China & 0 & \\
\hline Chinese Taipei & 0 & \\
\hline Singapore & 0 & \\
\hline South Korea & 6 & \\
\hline South Africa & 0 & \\
\hline India & 7 & \\
\hline Mexico & 7 & \\
\hline Israel & 0 & \\
\hline Russian Federation & 1 & \\
\hline Malaysia & 0 & \\
\hline Indonesia & 4 & \\
\hline Oman & 0 & \\
\hline Qatar & 0 & \\
\hline Saudi Arabia & 0 & \\
\hline Viet Nam & 0 & \\
\hline
\end{tabular}

*In 2010-2018: 15 cases.

Source: Data from WTO, 2019c.

The role of dispute settlement stems from the reason that effective enforcement of negotiated agreements is a prerequisite for a trading system to work. Otherwise, as the WTO is the rules-based system, it may cause concern about the efficiency of DS procedures. The WTO has no any special body with the authority to adjudicate and enforce the verdict in the disputed case. This is why so called „self-enforcing“ formula was introduced. It means that member states are aware of the consequences of retaliation in case of violation of any WTO agreement. Under the WTO rules retaliation is applied by a country affected by taking such a violating policy. This injured country itself enforces the terms of the agreement.

The WTO dispute settlement mechanism is a twostage process. The idea was to strengthen and legalized the DS procedure. In this context, the panel and its report gained stronger position becoming a kind of a lower level court. Adoption of panel report can only be blocked by a „negative consensus“. All of the above was associated with defining new rules regarding panels and establishing a standing Appellate Body (AB) as counterweight for removal of the possibility to block the panels. AB plays a role of an appellate court.

The argument for changing the principle of consensus in the WTO was to avoid blocking panels and their reports (GATT 1947 case). As noted, dispute settlement under the WTO is based on a „negative consensus“ principle. This means that all parties must consider the panel report as flawed which is rather highly unlikely (especially by the party who obtained a positive verdict). Therefore, a standing Appellate Body was introduced to the dispute settlement mechanism, the tasks of which is the legal interpretation of the panel report. The $\mathrm{AB}$ does not impose legal rulings what means it does not issue legal decisions. The AB has the authority to address legal issues only, not facts. The legal interpretation of rulings of the Appellate Body is a form of offset the inability to block panel reports.

All in all, the WTO's DSB process makes the trading system more secure and predictable. A dispute arises when a member government believes another member government is violating an agreement or a commitment that it has made in the WTO. It can be then concluded that DS mechanisms is very active, and dispute settlement can often be sufficient to resolve the matter in dispute. The system is based on clearly-defined rules, with timetables for completing a case. The appeal to the report is to be done by the $A B$ within another 90 days in line with the legal consistency of the report. The $\mathrm{AB}$ report is final and must be adopted by the DSB.

Summarizing, according to data published by the WTO since 1995 until 30 April 2019 (WTO, 2019):

1. over 583 disputes have been brought to the WTO,

2. initiated by approx. 50 members (31 December 2017), in relation to 20 WTO agreements,

3. a panel was established in respect of 340 disputes (around half of all disputes initiated), 
4. panel reports in 253 of these disputes (not all cases result in a panel report as the parties might settle their dispute even after a panel was established).

Data in Table 2 shows the number of DS cases involving some developing countries and the US, and in Table 3 recent WTO dispute settlement cases involving the US and China.

China was the most frequent respondents to US disputes with emerging economies. This country was a target of the US disputes also in recent period (Table 3). We may argue that this results from China's excessive engagement in both partners' trade turnovers. On the other hand, however, it also correspondents with Chinese refusal to give up its privileges due to "special and differential treatment" (S\&DT) as a developing nation at the WTO (Blustein, 2019; Ornelas, 2016). China claims that such treatment is its "fundamental right" (Zhou, 2019) and requests the same preferences as any other country under S\&DT (poorest members of the WTO). It is noted that developing country status of China has been right when it joined the WTO in 2001, but not today (Cutler, Doyle, 2019). Since then Chinese economy has been continued an impressive growth (Embury-Dennis, 2019).

China's behaviour on the global market we termed as an "economic factitious disorder". It can be explained as a permanent maintaining by China of the status of a developing country and the use of preferences for LDCs despite a real high level of economic development.

This observation leads us to our second postulate:

P2: The lack of a formal classification of developed and developing country within the WTO rules results in number of trade disputes due to an economic factitious disorder.

China is now the world's second largest economy. Trade Policy Review by WTO Secretariat during 20132017 (dated 6 June 2018) defines the Chinese economy as "an important engine of global growth (...) accounted for around $30 \%$ of global economic expansion during the review period" (WTO, 2018). Real GDP growth was $6.9 \%$ in 2015; $6.9 \%$ in 2016 and around $6.8 \%$ in 2017. There was also an unprecedented shift in the structure of economic development from the merchandise trade in GDP to the services sector now accounted for over $50 \%$ of GDP (Bekkers \& Teh, 2019). Nonetheless, Chinese government still indicates differences in income between the richest and the poorest, signaling that over 30 million of its citizens is still living in poverty (below the OECD average). On the other hand, however, twelve of the 100 largest companies are Chinese and the numerous world's billionaires are also from China (Cutler \& Doyle, 2019).

Table 3

WTO dispute settlement cases involving US and China, 1 January 2015 - 10 May 2019

\begin{tabular}{|c|c|c|c|c|}
\hline Subject & $\begin{array}{l}\text { Respondent/ } \\
\text { complainant }\end{array}$ & $\begin{array}{c}\text { Request for } \\
\text { consultation received }\end{array}$ & \begin{tabular}{|c|} 
Status (as at 11 December \\
2017)
\end{tabular} & $\begin{array}{l}\text { WTO document } \\
\text { series }\end{array}$ \\
\hline $\begin{array}{l}\text { Additional Duties on Certain Products from the } \\
\text { United States }\end{array}$ & China/United States & $16 / 06 / 2018$ & Panel composed & WT/DS558 \\
\hline $\begin{array}{l}\text { Certain Measures Concerning the Protection of } \\
\text { Intellectual Property Rights }\end{array}$ & China/ United States & $23 / 03 / 2018$ & In consultations & WT/DS542 \\
\hline Subsidies to Producers of Primary Aluminium & China/ United States & $12 / 01 / 2017$ & In consultations & WT/DS519 \\
\hline $\begin{array}{l}\text { Tariff Rate Quotas for Certain Agricultural } \\
\text { Products }\end{array}$ & China/ United States & $15 / 12 / 2016$ & Panel established & WT/DS517 \\
\hline Domestic Support for Agricultural Producers & China/ United States & $13 / 09 / 2016$ & Panel composed & WT/DS511 \\
\hline Export Duties on Certain Raw Materials & China/ United States & $13 / 07 / 2016$ & Panel established & WT/DS508 \\
\hline $\begin{array}{l}\text { Tax Measures Concerning Certain Domestically } \\
\text { Produced Aircraft }\end{array}$ & China/United States & $8 / 12 / 2015$ & In consultations & WT/DS501 \\
\hline $\begin{array}{l}\text { Measures Related to Demonstration Bases and } \\
\text { Common Service Platforms Programmes }\end{array}$ & China/United States & $11 / 02 / 2015$ & $\begin{array}{c}\text { Panel established, but not yet } \\
\text { composed }\end{array}$ & WT/DS489 \\
\hline $\begin{array}{l}\text { Measures Related to Price Comparison } \\
\text { Methodologies }\end{array}$ & United States/ China & $12 / 12 / 2016$ & In consultations & WT/DS515 \\
\hline $\begin{array}{l}\text { Certain Methodologies and their Application to } \\
\text { Anti-Dumping Proceedings }\end{array}$ & United States/ China & $22 / 05 / 2017$ & Retailation & WT/DS471 \\
\hline
\end{tabular}

Source: Data from WTO, 2019 c.

Nevertheless, after two decades of uninterrupted growth there was undoubtedly still a significant difference between GDP per capita in the US in 2017 - $\$ 59,501$ compared to $\$ 16,600$ - in China (Noland, 2017). However, it is a success and a big change as compared with the Chinese GDP per capita earlier, e.g. in 1986 when it amounted to only $\$ 677$ (Embury-Dennis, 2019).

The WTO has not have any classification or any benchmarks to determine and proper recognition as a "developed" or "developing" country. This means that a country individually self-declares its status in the WTO. As a consequence two thirds of WTO members consider themselves "developing countries" eligible for "special and preferential treatment" (Culter \& Doyle, 2019; WTO data, Zhou, 2019). The World Bank qualifies a "developed country" which achieves threshold value of its gross national income $(\mathrm{GNI})$ per capita at $\$ 12,055$. Due to the World Bank and OECD data files Chinese GNI per capita was $\$ 8,690$ in 2017 . Thus, on the basis of such a threshold, China qualifies for recognition as a "developing country" and it is eligible to keep its status and related privileges (Zhou, 2019).

All in all this signals that lack of ,clear criteria“ for the designation of level of development prevents from ,selfdesignation“ as „developed“ country, and results in an excessive number of ,developing“ countries. It also causes 
demands of breaking the general rules and principles what applies to the majority of members, China included. „To heal the situation“ American administration proposed to reduce (cut) the number of nations eligible for such special treatment, to reform categorization, and resignation from ,the good-faith“ of members in self-designating their status. The proposal was to classify WTO member as „developed“ providing it accounts for at least 0.5 per cent of world trade. It should refer to any member of the World Bank, OECD, G-20 whose trade meets the indicator. China fulfills this requirement as its share in world exports grew from 3.2 per cent in 2000 to 12.8 per cent in 2017 (WTO, 2019). The WTO members can also follow Taiwan that does not insist on S\&DT even though still having the status of developing country. Schneider-Petsinger from Chatham House added that due to nations' own definitions of what constitutes a „developed“ country in the WTO, Singapore or some of the G20 countries (India, South Korea) are still developing (Gonzales, 2019; Zhou, 2019).

The "developed-developing" dichotomy (classification of WTO members as the "least developing countries" (LDCs) is automatic and does not cause any controversy) does not serve the WTO membership well. Lester (2016) points to the absurdity of such solution and lowering the significance of the whole system, for example when the US will also declare itself "developing" (Gonzales, 2019; Lester, 2016).

It can be argued that as China's share in world trade increased significantly, the calls for bringing it to obey all standard rules and to open its market have intensified. We also claim that the problem regards many other WTO members and requires the changes in the classification as developed economies. All of the above led to the refusal of the US administration to reappoint one of its four remaining appeals layers (Embury-Dennis, 2019).

Nevertheless, despite a high evaluation of the effectiveness of the dispute system, the criticism of some solutions, especially the $\mathrm{AB}$ functioning, has increased recently (since the beginning of 2018). It resulted from the US administration - China trade dispute ("trade war") over steel and aluminum. Some academics explain this controversy by term "aggressive unilateralism of the US", which was for the first time used in 1990 by Bhagwati and Patrick (Bhagwati \& Patrick, 1991; Elms, 2018; "Economist", 2018).

Recent developments with the US blocking the appointment of members of the $\mathrm{AB}$ may lead to the paralysis of this body in December 2019 because of lacking the three panelists required to sign off on rulings. In accordance to para. 2 of Article 17 "Vacancies shall be filled as they arise", what is blocked by the US. It may lead to a 'domino effect' of trade retaliation.

On the other hand, the US criticism may also be understood. This controversy can be argued with usage of terminology in „The WTO Agreement" and whether it corresponds and is in line with its provisions. A closer look at arguments allows to identify a problem from a different angle. It can be explained that the working procedures are contradictory to a general rule (practice does not correspond to the theory contained in provisions):
1. The DSB appoints "persons to serve on the Appellate Body" (paras. 2, 3) and not "judges" (often referred to in this way);

2. Each person is appointed for a four-year term (para. 2) which can be extended for an additional period (of one year/the "reasonable period of time") "because the case is not finished yet"; for the implementation by a WTO Member of Appellate Body or panel rulings is recommended; in other words "to complete the disposition of the appeal";

3. "An appeal shall be limited to issues of law covered in the panel report and legal interpretations developed by the panel" (paras. 6, 12), and not facts; The WTO ruling here is very narrow.

4. Nonetheless, the AB uses its own merits and cites its own opinions in similar cases as precedents what is in contradiction to the Agreement;

5. The proceedings of the $\mathrm{AB}$ shall be confidential $\ldots$ in the light of the information provided and the statements made (para. 10);

6. "the proceedings shall not exceed 60 days from the date a party to the dispute formally notifies its decision to appeal to the date the AB circulates its report" (para. 5); the DSB is to inform in writing of the reason of any delay, but "in no case shall proceedings exceed 90 days".

To sum up, the final solution is for a country that violates the obligation to implement recommendations. However, in the dispute between the US and China, the each side of the dispute indicates the opposite party as guilty of the whole situation. On the other hand, efficiency of the Appellate Body activities deteriorate (Petersmann, 2019). There were 129 appeals filed in 1995-2014. In period 2014-2018 there were respectively 7 in 2014, then 7,8 , and 7 appeals with reports. Currently, in 2018 there were 10 appeals and in 2019, 3 appeals (WTO, 2019). The last digit signals the problem.

Thus, the most pressing issue remains the impasse in the dispute settlement mechanism, including the $A B$ nominations (Azevêdo, 2019).

Our findings confirm that observed problems of DSB and $\mathrm{AB}$ trigger erosion in the WTO system. On the one hand the lack of a formal classification of developed and developing countries allows to use preferential treatment under the S\&DT by in fact developed countries (i.e. China). On the other hand the "economic factitious disorder" leads to maintenance of the status of developing countries to benefit from the S\&DT. It is an evidence of the interrelation between the lack of the WTO classification of developed and developing countries and exemption of the MFN rule.

\section{Conclusions}

The multilateral trading system is an extension of the idea of a free market and it proves economic maturity of WTO members. It is the one of crucial issues regarding international business. However, the imperfection of WTO creates a hazard for international business by enhancing to protectionism in the global world. The most significant question for the WTO members is today: How to go from breakdown to breakthrough? 
The paralysis in the WTO functioning has to do with the loopholes in the organization's rules and principles. The deviations and exceptions of the WTO rules permit its members to compete "unfairly", what discourages countries to engage in trade negotiation. The increasing number, scope and diversity of RTAs confirm that the exemptions of the WTO rules and procedures became the rules. Thus it leads us to the conclusion that WTO should concentrate more on legislative changes to adjust to a new face of global economy. The Doha Round should be changed from the liberalization round to the legislation round. It is the best time or the latest time to start with the refreshing the WTO agreement and to adjust it for the new face of global world (Caporal at al., 2019). The need for change is also found in the understanding of the WTO board. As Azevedo pointed out: "This is the moment when some very basic principles of the organisation, principles of cooperation, principles of non-discrimination are being challenged and put into question. And I think that is very serious." (BBC News, 2018). Now it is the WTO Member States' turn.

Our findings indicate that the WTO lacks the mechanism to react and to prevent from such abuses. They were not envisaged by the WTO creators, what also suggests the need of the WTO reform. We identify with the opinion of Howse and Nocolaidis (2003:5) stated, "that the legitimacy of the multilateral trading order requires greater democratic contestability. The notion of global subsidiarity would be a more appropriate model for the WTO than that of a "federal" constitution. This notion incorporates three basic principles: institutional sensitivity, political inclusiveness, and top-down empowerment."
Moreover, taking into consideration international business, we agree that "with economic nationalism pulling the world towards isolationist protectionism, global supply chains may be strained but can sustain international trade" (Hilton, 2017: 5).

The analysis in our paper has limitations, which however provide opportunities for further research, as follows:

1. First of all, the WTO Member States should make the final decision, do the WTO is an universal organization or only international?

2. Second, are they still interested in multilateral trading system?

3. Third, if "yes" is the answer of the second question, should they reduce exemptions, because many of them during the last years transformed into "rules".

4. Fourth, if "not" is the answer of the second questions, do they need the WTO?

5. Fifth, what is for them more important aim: increasing international trade, international business, global development or national, populist interests?

6. Sixth, do they promote multilateral trading system or preferential regional trade agreements?

To sum up, we argue that the WTO rules-based system is indispensable for a proper functioning of international trade and business operations. It only needs to be improved to be able to defend against aggressive unilateralism, overwhelming regionalism, protectionist tendencies, etc. It also requires active participation of all Members to ensure efficiency of its disciplines.

\section{Reference}

Acharya R. (Ed.). (2016). Regional Trade Agreements and the Multilateral Trading System. Cambridge: Cambridge University Press. https://doi.org/10.1017/CBO9781316676493

Akyuz, Y., Milberg W., \& Wade, R. (2006). Great Controversies: Developing Countries and the Collapse of the Doha Round: A Forum. Challenge, 49(6), 6-19. https://doi.org/10.2753/0577-5132490601

Appleyard D. R., \& Field A. J., Jr. (2014). International Economics. 8th Edition. New York: McGraw-Hill/Irwin.

Azevedo, R. (2019). Research vital in making the balanced case for trade and the trading system, 24 June Available from internet: https://www.wto.org/english/news_e/spra_e/spra267_e.htm

Bagwell, K., Bown C. P., \& Staiger R. W. (2016). Is the WTO Passe? Journal of Economic Literature 2016, 54(4), 11251231. https://doi.org/10.1257/jel.20151192

Bagwell, K., \& Staiger, R. W. (2002). The Economics of the World Trading System, Cambridge, Massachusetts: MIT Press. https://doi.org/10.7551/mitpress/2628.001.0001

Bagwell, K., \& Staiger, R. W. (2014). Can the Doha Round be a Development Round? Setting a Place at the Table. In R. C. Feenstra, \& A. M. Taylor (Eds.), Globalization in an Age of Crisis Multilateral Economic Cooperation in the Twenty-First Century (pp. 91-124), Chicago and London: University of Chicago Press. https://doi.org/10.7208/chicago/9780226030890.003.0004

Baier, S. L., \& Bergstrand, J. H. (2007). Do free trade agreements actually increase members' international trade? Journal of International Economics, 71(1), 72-95. https://doi.org/10.1016/j.jinteco.2006.02.005

Baldwin, R., Evenett, S. J., \& Low, P. (2009). Beyond tariffs: multilateralizing non-tariff RTA commitments. In: R. Baldwin, P. Low (Eds), Multilateralizing Regionalism. Challenges for the Global Trading System (pp. 79-141), New York and Cambridge: Cambridge University Press. https://doi.org/10.1017/CBO9781139162111.005

Baldwin, R., \& Evenett, S. J. (2009). Introduction and recommendations for the G20. In R. Baldwin, S. J. Evenett (Eds), The collapse of global trade, murky protectionism, and the crisis: Recommendations for the G20. A VoxEU.org publication. Geneva-London: The Graduate Institute \& CEPR (European Commission). 
Baldwin, R. (2006). Multilateralizing Regionalism: Spaghetti Bowls as Building Blocks on the Path to Global Free Trade, The World Economy, 29 (11), 1451-1518. https://doi.org/10.3386/w12545

Bekkers E., \& Teh R. (2019). Potential Economic Effects of a Global Trade Conflict. Projecting the medium-run effects with the WTO Global Trade Model. WTO Staff Working Paper, ERSD-2019-04. World Trade Organization. Economic Research and Statistics Division. 1 April 2019.

Bellmann, C., Hepburn, J., \& Wilke, M. (2012). The Challenges Facing the Multilateral Trading System in Addressing Global Public Policy Objectives, International Development Policy, No. 3. https://doi.org/10.4000/poldev.1012

Bhagwati, J., \& Patrick, H. T. (1991). Aggressive Unilateralism. America's 301 Trade Policy and the World Trading System, Journal of International Economics, 31 (3/4), 387-389. https://doi.org/10.1016/0022-1996(91)90047-A

Bhagwati, J. (1995). US Trade Policy: The Infatuation with Free Trade Agreements. In J. Bhagwati \& A. Krueger (Eds), the Dangerous Drift to Preferential Trade Agreements. Washington, DC: AEI Press.

Bhagwati, J., \& Sutherland, P. (2011). The Doha Round: Setting a Deadline, Defining a Final Deal. Interim Report of the High Level Trade Experts Group, January. Available from internet: https://voxeu.org/sites/default/files/file/doharound-setting-deadline-defining-final-deal-interim-report-jan-2011.pdf.

Blustein, P. (2019). Schism. China, America and the Fracturing of the Global Trading System. Waterloo, ON Canada: Centre for International Governance Innovation (CIGI). https://doi.org/10.2307/j.ctvqmp1cb

Briscoe, S., \& Guha, K. (2006). A share of the spoils: Why policymakers fear 'lumpy' growth may not benefit all", Comment and Analysis, Financial Times, 28 August, p. 9.

Brown, G. W. (2012). The constitutionalization of what? Global Constitutionalism, 1(2), 201-228. https://doi.org/10. $1017 / \mathrm{S} 2045381712000056$

Caporal J., \& Reinsch W. \& Waddoups M. \& Tassin de Montaigu C. (2019). The WTO at a Crossroad. A Report of the CSIS Scholl Chair in International Business. Center for Strategic and International Studies (CSIS). Washington DC: September 2019. Available from internet: https://csis-prod.s3.amazonaws.com/s3fs-public/publication/190918_ Caporal\%20et\%20al_WTOCrossroad_WEB_v2.pdf

Carbonnier, G. (2012), International Development Policy: Aid, Emerging Economies and Global Policies. Graduate Institute of International and Development Studies, Palgrave MacMillan. https://doi.org/10.1007/978-1-137-00357-7

Chidede, T. (2018). Modernisation of the multilateral trading system - WTO reforms. Available from internet: https://www.tralac.org/blog/article/13682-modernisation-of-the-multilateral-trading-system-wto-reforms.htm

Curzon, G. (1965). Multilateral Commercial Diplomacy: GATT and its impact on national commercial policies and techniques. London: Michael Joseph.

Cutler, W., \& Doyle, K. (2019). China's Developing Country Status in the WTO: Time for an Upgrade? Independent, 25 January.

Das D. K. (2007). The Evolving Global Trade Architecture. Cheltenham. UK: Edward Elgar Publishing Limited. https://doi.org/10.4337/9781847205353

Deblock, C. (2016-7). From regionalism to cross-regionalism. Great Insights Magazine, 5(6), 8-9.

Devuyst, Y., \& Serdarevic, A. (2007). The World Trade Organization and Regional Trade Agreements: Bridging the Constitutional Credibility Gap. Duke Journal of Comparative and International Law, 18(1), 1-75.

Drabek, Z. (2010). Introduction. In Z. Drabek (Ed.) Is the World Trade Organization Attractive Enough for Emerging Economies? Critical Essays on the Multilateral Trading System (pp.1-10). London: Palgrave Macmillan. https://doi.org/10.1057/9780230250826_1

Elms, D. (2018). US-China: Kicking the can further down the road. Available from internet: http://asiantradecentre.org/talkingtrade/us-china-kicking-the-can-further-down-the-road

Embury-Dennis, T. (2019). China refuses to give up 'developing country' status at WTO, despite Trump administration pressure. Independent, 10 April.

Ethier, W. J. (1995). Modern International Economics, New York - London: W.W. Norton \& Company.

Feng, L., Li, Z., \& Swenson, D. L. (2017). Trade policy uncertainty and exports: Evidence from China's WTO accession. Journal of International Economics 106, 20-36. https://doi.org/10.1016/j.jinteco.2016.12.009

Fetzer, T., \& Schwarz, C. (2019). Tariffs and politics: evidence from Trump's trade wars. CESifo Working Paper No. 7553. Category 8: Trade Policy. University of Warwick \& CAGE. https://doi.org/10.2139/ssrn.3349000 
Gallagher, P. (2005). The First Ten Years of the WTO: 1995-2005. New York and Cambridge: Cambridge University Press. https://doi.org/10.30875/dbbfd01d-en

Gallas, D. (2018). WTO chief warns of worst crisis in global trade since 1947. BBC News, 30 November. Available from internet: https://www.bbc.com/news/business-46395379

Gantz D. A. (2013). Liberalizing International Trade after Doha. Multilateral, Plurilateral, Regional, and Unilateral Initiatives. New York: Cambridge University Press. https://doi.org/10.1017/CBO9781139525282

Gonzalez, A., \& Veron N. (2019). EU Trade Policy amid the China-US Clash: Caught in the Cross-Fire? Peterson Institute for International Economics (PIIE), August 2019. Working Paper 19-13. Available from internet: https://reinhardbuetikofer.eu/wp-content/uploads/2019/07/EU-trade-policy-amid-the-China-US-clash_final-version9-July.pdf. https://doi.org/10.2139/ssrn.3431323

Greenaway, D., Morgan, W., \& Wright, P. (2002). Trade Liberalization and Growth in Developing Countries. Journal of Development Economics, 67, 229-244. Available from internet: http://www.sciencedirect.com/science/ article/pii/S0304-3878(01)00185-7. https://doi.org/10.1016/S0304-3878(01)00185-7

Guarino, A. S. (2018). The Economic Effects of Trade Protectionism, Economic Forecasts from the World's Leading Economists, Focus Economics, March 1.

Haddoud M. Y., Jones P., \& Newbery R. (2015). Regional Trade Agreements and Developing Countries' Trade Performance: Evidence from Algeria and the European Union Association Agreement. Journal of North African Research in Business, Vol. 2015 (2015), Article ID 143938. https://doi.org/10.5171/2015.143938

Henderson, D. (2003). WTO 2002: imaginary crisis, real problems. Cambridge University Press: 14 February 2003

Hilton, A. (2017). The impact of protectionism on international trade. Manufacturing. Supply chain strategies, Raconteur, RCNT.EU/21T69, February 23: 20.06.2019

Hoekman B. M., \& Kostecki M. M. (2009), The Political Economy of the World Trading System. The WTO and Beyond, Oxford - New York: Oxford University Press.

Howse, R., \& Nocolaidis, K. (2003). Enhancing WTO legitimacy: Constitutionalization of global subsidiarity? Governance: An International Journal of Policy. Administration \& Institutions, 16(1), 73-94. https://doi.org/10.1111/1468-0491.00205

Ismail, F. (2005). Mainstreaming Development in the World Trade Organisation, Journal of World Trade, 39(1), 11-21

Jones, K. (2015). Reconstructing the World Trade Organization for 21st Century. An Institutional Approach, Oxford New York: Oxford University Press. https://doi.org/10.1093/acprof:oso/9780199366040.001.0001

Kernohan D., \& Edwards, T. H. (2006). The fall of Doha and the rise of regionalism?, CEPS Policy Brief, 111, 1-4. Available from internet: http://aei.pitt.edu/11717/1/1377.pdf

Krugman P. R., Obstfeld M., \& Melitz M. J. (2012). International Economics. Theory \& Policy, Essex: Pearson Education Limited (Addison-Wesley).

Larch, M., Monteiro, J. A., Piermartini, R., \& Yotov, Y.V. (2019). On the Effects of GATT/WTO Membership on Trade: They are Positive and Large after All. WTO Staff Working Paper No. ERSD-2019-09.

Lawrence R. Z. (2018). US-China Trade Frictions and the Global Trading System. In J. Ha \& A. S. Posen (Eds), USChina Economic Relations: From Conflict to Solutions. Peterson Institute for International Economics. PIIE Briefing Part I, 18-1.

Lester, S. (2016). Is the Doha Round Over? The WTO's Negotiating Agenda for 2016 and Beyond, Herbert A. Stifel for Trade Policy Studies, Free Trade Bulletin, 64 (February 11), 1-4.

Lynch, D. A. (2010), Trade and Globalization. An Introduction to Regional Trade Agreements, Rowman \& Littlefield Publisher.

Mlinaric, F., Oplotnik, Z. J., \& Brezovnik, B. (2018). Economic Limits of (de) Regulation in Legal Services Market. Inzinerine Ekonomika-Engineering Economics, 29(3), 291-301. https://doi.org/10.5755/j01.ee.29.3.19826

Noland, M. (2017). The Risks and Costs of Trade Wars. In: A. S. Posen \& J. Ha (Eds), US-China Cooperation in a Changing Global Economy. Peterson Institute for International Economics. PIIE Briefing 17-1.

Ornelas, E. (2016). Special and Differential Treatment for Developing Countries, CESifo Working Paper Series, 5823. Available from internet: https://ssrn.com/abstract=2766933. https://doi.org/10.1016/bs.hescop.2016.04.011

Pal, P. (2008). Regional Trade Agreements and Improved Market Access in Developed Countries: The Evidence. 
Krystyna Zoladkiewicz, Renata Orlowska. Imperfection of the World Trade Organization as a Hazard for International Business

Economic and Political Weekly, 43(48) (Nov. 29 - Dec. 5, 2008), pp. 83-92. https://www.jstor.org/stable/40278241

Panagariya, A. (2000). Preferential Trade Liberalization: The Traditional Theory and New Developments. Journal of Economic Literature, XXXVIII (June), 287-331. https://doi.org/10.1257/jel.38.2.287

Panagariya, A. (2007). Trade Dimension of Globalization: Multilateralism or Regionalism?, WTO Public Forum: How can the WTO Help Harness Globalization, Geneva October 4-5 (presentation received from Author).

Pauwelyn, J. (2005) 'The Sutherland Report: A Missed Opportunity for Genuine Debate on Trade, Globalization and Reforming the WTO. Journal of International Economic Law, 8(2), pp. 329-46. https://doi.org/10. 1093/jielaw/jgi023

Petersmann, E. (2019). How Should WTO Members React to Their WTO Crises? World Trade Review, 18(3), 503-525. https://doi.org/10.1017/S1474745619000144

Pilinkiene, V. (2016). Trade Openness, Economic Growth and Competitiveness. The Case of the Central and Eastern European Countries. Inzinerine Ekonomika-Engineering Economics, 27(2), 185-194. https://doi.org/10.5755/ j01.ee.27.2.14013

Pomfret, R. (2008). Lecture Notes on International Trade Theory and Policy, Singapore: World Scientific Publishing. https://doi.org/10.1142/6849

Reinert, K. A. (2012). An Introduction to International Economics. New Perspectives on the World Economy. Cambridge and New York: Cambridge University Press.

Sachs, J., \& Warner, A. (1995). Economic Reform and the Process of Global Integration. Brookings Papers on Economic Activity, 1. https://doi.org/10.2307/2534573

Salvatore, D. (2012). Introduction to International Economics, Singapore: John Wiley and Sons.

Sorgho, Z. (2016). RTAs' Proliferation and Trade-Diversion Effects: Evidence of the "Spaghetti Bowl" Phenomenon. World Economy, 39 (2), 285-300. https://doi.org/10.1111/twec.12295

Sun, P., \& Heshmati, A. (2010). International Trade and its Effects on Economic Growth in China. IZA DP, 5151, 1-36

The Economist (2018). March 10th, April 14th.

The WTO Agreements. (2017) Marrakesh Agreement Establishing the World Trade Organization and its Annexes, Cambridge: World Trade Organization \& Cambridge University Press.

Trebilcock M. J., \& Howse R. (1999). The Regulation of International Trade. 2nd Edition. London and New York: Routledge.

Ullah, M. S., \& Inaba, K. (2011). Impact of RTA and PTA on Bangladesh's Export: Application of a Gravity Model. Journal of Industry Competition and Trade. December 2011, 12(4). https://doi.org/10.1007/s10842-011-0116-3

Vanek, J. (1968). The Factor Proportions Theory: the N-Factor Case. Kyklos - International Review for Social Sciences. 21(November), 749-756. https://doi.org/10.1111/j.1467-6435.1968.tb00141.x

VanGraasstek, C. (2013). The History and Future of the World Trade Organization. Geneva: World Trade Organization. https://doi.org/10.30875/14b6987e-en

Vernon, R. (1979). The Product Cycle Hypothesis in a New International Environment. Oxford Bulletin of Economics and Statistics, 41(4), 255-267. https://doi.org/10.1111/j.1468-0084.1979.mp41004002.x

Wachiarg, R., \& Welch, K. H. (2008). Trade Liberalization and Growth: New Evidence. World Bank Economic Review, 22(2), 187-231. https://doi.org/10.1093/wber/lhn007

Wagner, J. (2011). International trade and firm performance: A survey of empirical studies since 2006. IZA Discussion Papers 5916, Institute for the Study of Labor (IZA).

Wilkinson, R. (2007). Language, power and the breakdown of multilateral trade negotiations, New Political Economy of Globalization, 20-21 April. https://doi.org/10.1080/09692290802587734

Wolf, M. (2001). What the world needs from the multilateral trading system? In G. P. Sampson (Ed.). The Role of the World Trade Organization in Global Governance (pp.183-208). Tokyo: United Nations University Press.

Wroblewski, M., \& Stecz, K. (2019). WTO Reform-Current Status and Prospects. Research Papers of Wroclaw University of Economics, 63(3). https://doi.org/10.15611/pn.2019.3.09

WTO (1997, 2007). Speeches of Director-Generals: Renato Ruggiero, Pascal Lamy. Available from internet: 
WwW.wto.org

WTO (2009). The Doha Round Texts and Related Documents, Geneva: World Trade Organization

WTO (2018). Trade Policy Review, China, WTO Secretariat, Geneva, 06/06/2018. Available from internet: https://www.wto.org/english/tratop_e/tpr_e/tp475_e.htm

WTO (2019a). Available from internet: www.wto.org

WTO (2019b). Available from internet: http://rtais.wto.org/UI/PublicMaintainRTAHome.aspx

WTO, (2019c). Available from internet: https://www.wto.org/english/tratop_e/dispu_e/dispu_e.htm

Wu, C. (2007). An Outline of International Price Theories, Auburn, Alabama: Ludwig von Mises Institute.

Zedillo, E. (2007), Introduction. In Hoekman, B.M., Olarreaga, M. (Eds.), Global Trade and Poor Nations. The Poverty Impacts and Policy Implications of Liberalization. Brookings Institution Press.

Zhou, C. (2019). Why is emerging global superpower China still categorised as a 'developing' country? ABC News. Australia, 11 April.

Zoellick, R. B. (2008). Modernizing Multilateralism and Markets, Annual Meeting Board of Governors of the World Bank Group. Washington, DC October 13, 2008. https://www.imf.org/external/am/2008/speeches/pr03e.pdf. https://doi.org/10.1596/29758

The article has been reviewed. Received in October 2019; accepted in June 2020. 